UNTAG Law Review (ULREV)

Volume 1, Issue 1, May 2017, PP 15-27

ISSN 2549-4910 (online) \& ISSN 2579-5279 (print)

http://jurnal.untagsmg.ac.id/indeks.php/ulrev/indeks

www.fakhukum.untagsmg.ac.id

\title{
IMPLEMENTATION OF THE DEVELOPMENT PROGRAM THAT JUST AS THE PRO-POOR GOVERNMENT POLICIES
}

\author{
Sri Suatmiati \\ Faculty of Law \\ Universitas Muhammadiyah Palembang
}

\begin{abstract}
In Several states, social security for citizens is place to protect marginalized groups in order to maintain access to public services are rudimentary, such as services to meet the needs from the perspective of political economy known as basic need. Public welfare provision in the state system includes services in the areas of basic education, health and housing are cheap and good quality, if Necessary, free as in Western Europe is a cluster of countries are quite intense in terms of the welfare state principles. Free education and health is a major concern in Western Europe to get subsidies. The Data agency (BPS) said that the Indonesian population in 2010 income Rp.27,0 million a year.

There are poor people Whose population is 80 percent of the population only contributes about 20 percent of GDP. There are the wealthy once or people who enter the category earn more than 30,000 dollars a year, but there are Also people with disabilities living income or $\$ 2$ dollars per day ( 730 dollars a year), the which are still 100 million people. It means there is a huge gap. The words fair, equitable, wellbeing and prosperity was growing dimmer and the faint sound. This condition shows how there is no equity in income Because there is no strong will to realize the vision for the welfare of society. Impossible Anti-poverty program run properly if the governance of the state and society is not yet fully base on the welfare state system. Anti-poverty programs intertwine with the application of individual taxation that is progressive. If taxation without concept, poverty reduction strategy with the government has not gone According to the terms of the welfare state that is pro-poor.
\end{abstract}

Keyword : The Development Program, Government Policies

\section{INTRODUCTION}

In the early days of independence in accordance with the implementation of the decolonization process, the Development policy implemented to carry out the construction of a centralized in the hands of the central authorities tend to be dominant. The belief of national elites who contributed to liberate the country believes that prosperity can only be obtained quickly through "the above activities", which can be distributed directly to a natural process called 'trickle-down effects'. Or development activities remain to be implemented in accordance with the planned autonomy through a process managed by both top down. But in fact the government should also implement its development buttom up involving the 
community and society as well enjoy the fruits of development, understood that people participate actively in carrying out activities in life as a progressive legal characteristics.

According Satjipto Raharjo, law must return to the basic philosophy that is legal for humans. With that philosophy, becomes decisive and orientation point of law. Legal duty to serve man rather than vice versa. If the law in the service of man then the law must adjust the values $\square \square$ of human needs, interests of the people (wellbeing and happiness) should be widened orientation point and the ultimate goal of the implementation of the law.

Nuanced reformative policy options namely the implementation of development involving elements of society that populist often called civil society that is different from the policy at the time of decolonization called according Soetandyo is a policy to seek prior strengthening social infrastructure, as well as for development and community empowerment citizens in the life of the state, through transformative process.

Transfomatif development process is a process that drives change and internal development of the social order dependency configured comply vertical relationship model "Kawula Gusti" configured to the new order of equality among citizens. The tranformation like this requires local institutions are active and progressive move from within, from the environment local communities, this is the institution by Berger and Neuhaus called mediating structure. It is impossible, as said by Soetandyo that the 'Tri Hita Karana' or 'feelino local and ethnic wuno' that it could be accepted together, from Sabang to Merauke.

Since the 1960s, there are many authors and statements that explicitly distance themselves from approaches that simply watching one dimension in order to construct the development targets, such as economic growth, and filed a multidimensional target catalog. Specialists are very influent transition. It is Dudley Seers (1974), who refused growth without the development of society and call the three main strategic objectives, namely to reduce poverty, unemployment and social inequality. According to the Seers, the three priorities it is absolutely necessary to develop human potential. "Reports Rio '(Tinbergen, 1976) covers a broader range of target again, namely equality, freedom, democracy, solidarity, cultural diversity, and environmental protection. Gerald Braun (1987) emphasizes the basic needs nonmaterial which he is an environment that consists of the protection of cultural identity and political autonomy, resistance to imitation patterns of Western Seara is not critical, as well as the determination of material needs.

In their book on economic development, which is widely used in developing countries (first edition published in 1977), Todaro and Smith (2003; until the 7th edition Todaro alone) mentions three strategic goals (prescriptive) are mutually supportive and complementary, to stem from the analysis (descriptive) interrelationships of many factors. Three goals is physical life assurance through the ability to meet basic needs, human dignity and freedom of every occupation, both physically and spiritually as a condition for more choices of economic, social, and political. These strategic objectives should attract a lot of attention as operationalized in their work.

More detailed targets catalog proposed by Nohlen and Nuscheler (1992a, 64-75) with the title of Segi Five Magis Community Development. The catalog includes the following five elements:

1. Qualitative growth, reducing poverty and protecting the environment (sustainability) as an essential condition, with a note, the growth was not enough to meet basic needs and the equitable distribution of income; 
2. Employment opportunities, both as an instrumental value, ie productive jobs and generate sufficient revenue, as well as a value in itself, namely the opportunity to manifest themselves;

3. Equality / justice (as a qualitative correction factor to growth), through equitable justice and public access to public goods and services;

4. Participation, as an opportunity to come speak and participate in social, in the sense of "development from below"; 5. Independence from / independence, as an opportunity to pursue economic and political development that is self-sufficient.

The goals, which was first formulated in 1974 and is valid today, according to the dimensions they need complete by ecological and economic order relying on the market and at the same time socially patterned. Nohlen and Nuscheler summarizes the definition of community development as follows:

"The development of the productive forces on the basis of their own initiative in order to provide goods and services for the whole community, both materially for survival and cultural make life more humane, as well as an order of arrangement of social and political guarantees all members of society will have equal opportunity, good to participate in political decisionmaking as well as to share in the prosperity cultivated together. "(Nohlen and Nuscheler, 1992a, 73)

Similarly interesting approach of Dieter Senghaas (2002) who filed a hexagon the process of civilization, highly influence by great works of Norbert Elias (1978) about the "process of civilization". According Senghaas, modern society characterized and challenged by politicization and pluralization, both the residents and the community, due to urbanization, more dense social relationships, literacy, upward mobility, as well as the effects of international demonstrations. Of all the emerging problems, namely how the public can be arranged properly, especially how conflicts are inevitable could be solved properly thus created a peaceful coexistence.

Based on the historical development in the West with a lot of conflict, he found six basic elements that form the basis of modern civilization in the West are generally able to solve conflicts without violence. Six elements, intertwined with each other and complement each other, are:

1. Monopoly countries in using physical violence, meaning that residents are not allowed to wear a weapon to defend yourself (Vigilante), because the task was handled by a police state;

2. State law with various institutions (courts, prosecutors, lawyers) as a rule of the game to steer and control the state's monopoly on violence, especially to avoid the emergence of a dictator.

3. Democratic participation as the basis for changing and developing the law in accordance with the changing times not to freeze so they no longer reflect the aspirations of the people;

4. Control of affection at the individual level, both with internalize a culture without violence and through the interdependence of the many roles played by each person. Thus, there will be no absolute conflict of the whole of existence, but the fragmentation of conflict softer and more easily overcome;

5. Fairness in the distribution of income that should compensate for the market system 
(capitalism) and ensure the participation of folk material. This principle aims to avoid inequality is too great, even if the benchmark of inequality that can not be accepted anymore different;

6. Cultural conflict that civilized and free of violence, in society means that there is some sort of a deal and a strong will to solve the existing conflicts by peaceful means. These elements are essential for a modern political culture. According Senghaas, it evolved in western civilization is not because it is a sort of intrinsic elements of that culture, but rather "against the will" of being forced by changing circumstances of modern society. Through his thesis, a cultural essentialism (or culturalism) rejected, as if Western culture from the beginning to get there. Based on the way the vision, Senghaas argues that developing countries also inevitably have to take a similar path since also been seized with the process of modernization, though perhaps by developing different institutional forms.

\section{DISCUSSION}

\section{Implementation Of The Development Program That Just As The Pro-Poor Government Policies}

When the economic crisis hit the United States since about July 2007 and turned into a large explosion in mid-September 2008 with the collapse of major investment banks, then the United States also immediately shifted back into the welfare state in XXI century now. As is known to the United States is a country that is widely known as a champion of democracy capitalistic and even be in the forefront in terms of governance of the state and society are fully capitalistic oriented. This condition does not allow the United States to walk based on the principles of the welfare state. However, the collapse of investment banks in mid September 2008 highlighted the signal that the United States eventually shifted again into the welfare state. Bail Out Program of the George W. Bush administration against the three US automakers-Ford, General Motors and Chrysler is a real step socialist dimension and therefore very close to the conception of the welfare state.

Thorough administration of George W. Bush has decided to impose a bailout scheme (Baill out) amounted to US $\$ 700$ billion to the American automotive industry. Baill out of it is Skeme that are beyond the loan. President-elect Barack Obama, even when it has not been sworn in asking President Bush to immediately support the disbursement of aid to the automotive sector. The reason, automotive is a labor-intensive sector in the US are supported by a variety of other supporting industries. Moreover, the automobile companies started to reduce the number of employees, then Baill out is seen as the right option. But the undeniable fact that this is to emphasize that the US is not completely patterned capitalistic, if also not completely socialistic, the elements begin to color welfare US economy country.

Further implications of state proficiency level is open space to reconsider the meaning and nature of the welfare state (welfaar state) in the XXI century. Having previously declared a failure by social scientists. The conception of the welfare state now has an empirical foundation for reconsideration implementation. Recent developments in the economy as the US economy shows a fundamental shift in the pendulum of a free market economy towards the welfare state. Compare with Indonesia with the disbursement of funds Baill Out Century although no impact to the Indonesian state economic supported by people such as palm oil plantations and rubber which causes every year there is an increase in GDP of society.

The welfare state in its generic sense is a concept, a paradigm and framework of action of the 
government in which the state sector a key role in providing or promoting the protection and welfare for every citizen. This conception is contrary to 'state capitalist' who allow every citizen to make efforts in self-off of state intervention in creating prosperity. Thus, the welfare state put forward the principles of equality of opportunity for every citizen to prosperous.

The degree and specific dimensions, the welfare state should not and do not necessarily equate to socialism. This is because, socialism emphasizes the absence of ownership of the factors of economic production controlled and owned by the state. Socialism has a generic meaning that the "system of social organization in wich properly and the distribution of income are subject to social control rather than individual determination or market forces". Something fundamental in the welfare state is the implementation of social security for every citizen.

In several state, social security for citizens in place to protect marginalized groups in order to continue to have access to public service in a rudimentary, such as services to meet the needs from the perspective of political economy known as basic need.

Public welfare provision in the state system includes services in the areas of basic education, health and housing are cheap and good quality, if necessary, free as in Western Europe is a cluster of countries are quite intense in terms of run-rinsip principles of the welfare state. Free education and health is a major concern in Western Europe to get subsidies.

The reconstruction is done by analyzing distortions through interpretation of the reality of the law, both regarding the behavior of law and text settings related to the management of development (welfare, education) who has the authority as legislators (role making institution), the authority of law enforcement (rule sanctioning institution) or the authority is public or stakeholders (role accupation). Since 1953-1957, China teleh formulate a five-year development strategy. This pattern of development as been applied in Indonesia when the government controlled by President Soeharto.

China's development strategy has always discussed, evaluated, and strengthened every year in the National Congress Party (Communist) by taking into account the dynamics and challenges of domestic and world developments. The year 2010 is the end 'Five Years Development Planning' II China. 'Five Years Development Planning' was executed while resting and directed at achieving the vision and goals of development in 2050 where China has had to become a developed country. China's national development planning can not be separated from the role of the National Development and Reform Commission (National Development and Reform Commission / NDRC).

NDRC is superministry authorized institutions outlining the vision, mission and policies of the CCP into national development planning as well as provide guidance / direction for the various programs and China's economic development strategy, both short, medium and long term. Government programs and other ministries and local government should be based on the NDRC plan. It is also supported by the placement policy of CCP officials (commissioners) at several levels of management, both in the central and local government, state, university or government. This was done to ensure and oversee the vision and national development programs so as not to deviate from the line of grand national strategy.

The pattern is somewhat similar to that of Suharto when in power for 32 years. When the networks and relationships of three lanes military, bureaucracy and Golkar (ABG) is so strong that the implementation of development which is reflected in Repelita can be controlled. At that time many of the military officers who are placed as inspector general or commissioner in a number of departments. 
Efforts made by National Economic Committee (KEN) are far to come to China in the context of the preparation of the master plan of the Indonesian economy would be useless if it does not have the support of all stakeholders in Indonesia.

Exposure of Economic Prospects Nasional Indonesia in 2011 were delivered KEN in particular focus attended private entrepreneurs and leaders of state-owned enterprises in Jakarta (Monday, December 21, 2011), almost the same as the NDRC in China, with the proposed conditions and global economic challenges for Indonesia fore, in the future there will be an action plan concerning the business developed. To formulate it, KEN would involve employers' associations. Homework is still pending some of which this year limitations provision infrastructure, Swelling control energy subsidies and government spending absorptive capacity. This could be a threat to the sustainability of economic growth in 2011 . Chairul expect the government to improve the system, processes, budgeting and expenditure procedures, at both central and local levels. Separately, Chairman of the Indonesian Employers Association (Apindo) Sofyan Wanandi argues, in 2010 became the only locomotive of economic growth in Indonesia. According to the Government ran out of time to deal with political affairs. As a result, Indonesia's economic growth slowest in comparison with countries in Southeast Asia.

In the courtyard of a wider welfare state system has close relation to the government's programs to improve or alleviate poverty. Anti-poverty programs is even considered as the most important dimension of poverty implementation has the welfare state system.

Based on data from the Central Bureau of Statistics, the poverty rate fell from $14.2 \%$ (2009) to $13.3 \%$ (2010) million of the 32 million previously, and 60\% are in rural areas. This figure is actually confusing because the reception is poor rice quota of about 17.5 million if there were 4 people in one family. The figures also do not reflect $28 \%$ of children with less weight and $44 \%$ with less growth as stunted. Poverty eradication programs at the eradication of corruption if the government can not overcome the corruption of state officials. According to the Corruption Watch International since 2004-2010, there were at least 18 governors, one vice governor, 17 mayors, deputy mayors 8,84 regent and deputy regent tripped 19 corruption cases.

Impossible anti poverty program run properly if the governance of the state and society is not yet fully based on the welfare state anti-poverty program intertwined with the application of individual taxation that is progressive. And poverty alleviation require that something more fundamental that the rich man and the greater the nominal amount or percentage of tax that must be borne. Conversely, if included in the category of poor, someone will be in a provision that is entirely free from tax burdens. If taxation without concept, poverty reduction strategy with the government has not gone according to the framework of the welfare state. Poverty alleviation would be one thing, and a progressive tax is another. The welfare state is a system that offers the finish against the emergence of a contradiction between the two.

In various studies on the welfare state after World War II, the British called the country a certain degree of applying the concept of the welfare state. Based on the premise economist William Henry Beveridge (1879-1963), especially in his book titled Beveridge Social Insurance and Allied Services, British produce minded policies of the welfare state. The arguments presented Beveridge associated with major hazards that may be caused by unemployment on a large scale is spawned poverty on a large scale as well

Central Bureau of Statistics announced the growth of Gross Domestic Product in 2010 increased by 6.1 percent against 2009, meaning far from the original target of only 5.8 percent. 
The amount of the Gross Domestic Product (GDP) of Indonesia in 2010 at current prices reached Rp.6.422,9 trillion, while at constant prices (2000) reached Rp.2,310 trillion. Of the amount of GDP at current prices tesebut if divided by the population Rp.2.70 or 3004.9 million US dollars, while in 2009 amounted Rp.23,9 million (US \$2,349,6).

The economic program could increase even more if there is a government program that is massive and massively as big bangnya. The data agency said the Indonesian population in 2010 income Rp.27,0 million a year. There are poor people whose population is 80 percent of the population only contributes about 20 percent of GDP. There are the wealthy once or people who enter the category of income to 30,000 US dollars a year, but there are also people with disabilities living income or $\$ 2$ dollars per day ( 730 dollars a year), which are still 100 million people. It means there is a huge gap. The words fair, equitable, well-being and prosperity was growing dimmer and the faint sound. The sectors that recorded the highest growth are transport and communications, which reached 13.5 percent of the agricultural sector 42 million people, only grew 2.9 percent. In addition to the gap between population, inequality between regions (Indonesia's economic structure is also the case of 57.8 percent of the GDP of the fourth quarter of 2010, for example, is still a contribution to Java with the first order DKI Jakarta (16.5), followed by East Java (14.8) percent in the second sequence that has shifted the ratings West Java (14.3 percent). Kalimantan rich in natural resources, contribute only 9.1 percent, 23.2 percent Sumatra and Sulawesi 4,7 percent only. This condition shows how there is no equity in income because there is no strong will to realize the vision for the welfare of society.

On the one hand, government should not remain silent or stand idly facing this reality. The government must develop a variety of initiatives and efforts to eliminate unemployment. Settlement of the unemployment problem is half of the completion of poverty. On the other hand, there is a new understanding that people are free (free society) should be understood as a society liberated from the shackles of unemployment. If unemployment is still rampant in a free society, it is a meaningful apparent freedom. This reminds us to the Isaiah Berlin statement: "... political liberty is useless without the economic strength ...". very obvious if Beveridge influenced mazab Keynesian economic thinking, a school of thought which necessitates government intervention to the economic sphere to ensure the enforcement of the prosperity and welfare of the community. Beveridge then referred to as the man who played a major role creating the blueprint the welfare state in the UK, in the post World War II.

In the United States, the conception of the welfare state is manifest in social and economic programs initiated by the New Deal United States President Franklin D.Roosevelt to -32 (1882-1945). During the period 1933-1939, President Franklin D.Roosevelt necessitates the administration in the United States to intervene in the economy and the social life. Under the leadership of national, carried out the renewal of the industrial sector, agriculture, labor, housing and water supply. Once the size of the intervention, to the extent that the US government at the time was described as 'vastly increasing the scope of the federal goverment's activities'.

As a nomenclature New Deal actually do not stand alone, but are in the same meaning to the phrase 'new deal' for the 'forgotten man', which roughly means 'a new twist for those who have been forgotten'. An interesting case is highlighted in the context of the New Deal welfare state is treated as negation as lassez-faire, which is a political philosophy which forbids regulation of the industry and the economy. Laissez faire is a style of US domestic implementation of the concept that hand invieseable first conceived by modern capitalism, Adam Smith (1723- 
1790). New Deal embraces almost total economic regulation, but regulation was entirely devoted to creating a balance in order circumvent the possibility of conflict of economic interest.

The welfare state in the concept of the New Deal reflected very strong efforts on closely held its speed increase in the number of unemployment in the United States. Something then become something valuable New Deal is unemployment alleviation through employment was temporary. Government funding to bear short-term goals for hiring the unemployed through the development of construction projects and also through what is known as a youth work in the national forests. This is then known with short term aid and to provide temporary jobs. Before 1935, the New Deal in the revitalization efforts of two things: 1). Revitalization of the various business areas have functioned as a huge mass of the US economy bumper; 2) revitalization of agriculture and rural communities. Indonesia is being initiated in Agricultural Law and Food Adequacy Program. To move industrial activities, the New Deal sparked new regulations with regard to wages, working hours, child labor and so on. In essence, the workers get a formal legal basis to raise the bargaining position faced by the industrialists. The New Deal also focused on financial sector regulation for the sake of blocking off the possibility of a repeat of the fall of the stock market is very strategic in 1929 with all its consequences.

New Deal that encourage the birth of bank deposit insurance agency named the Federal Deposit Insurance Corporation (FDIC). Through the FDIC, the government provides a guarantee to any deposit or deposits of the banking blanket guarantee born from the womb of the New Deal. At the same time, the Securities and Exchange Commission (SEC) was established to protect investors from various efforts deceit cheat in the stock market. In agriculture, New Deal coordinate agricultural programs through institutions Agriculture Adjustment Administration (AAA). What made through AAA is raising the price of commodities through the production control or through the provision of subsidies to farmers. And through institutional Tennessee Valley Authority (TVA), the government provides cheap electricity, prevent flooding, make improvements navigation system and so on.

In 1935, the New Deal is more focused on efforts to provide assistance to the workers and the marginalized in urban areas. Through the birth of the Wagner Act in 1935 there was an increase in the federal government's authority to suvervise or oversee the welfare of workers at various levels and types of industries. The legislative process towards the birth of the Wagner Act adalah'organisasi the workers' and 'industrial relations', initiated by Senator Roberty Wagner (1910-1991) led to the birth of a body that is important for an agency effort called the National Labour Relations Board (NLRB). Social security is based on the New Deal scheme designed for the period 1935-1939 allows the 'the forgoten', the elderly, the disabled and the unemployed in urban getting insurance. In the urban areas the United States since 1938 provisions apply maximum working hours and minimum wage.

The study is based on political economy persfective suggests that the Great Depression occurred during the period 1929 to the beginning of 1940 brought disorder to the US economy because of the gap that separates rich and poor are very keen to be marked by the collapse of the drastic economic production, delays in product marketing and commodities and stagnation in the services sector, is really going on unemployment and poverty are very broad. The Great Depression illustrates the fundamental weaknesses in the US economy. In 1935, the New Deal is more focused on efforts to provide assistance to the workers and the marginalized in urban areas. Through the birth of the Wagner Act in 1935 there was an increase in the federal government's authority to mesuvervisi or oversee the welfare of workers at various levels and 
types of industries. The legislative process towards the birth of the Wagner Act is ' the workers organization" and 'industrial relations', initiated by Senator Roberty Wagner (1910-1991) led to the birth of a body that is important for an agency effort called the National Labour Relations Board (NLRB). Social security is based on the New Deal scheme designed for the period 1935-1939 allows the 'the forgooteen', the elderly, the disabled and the unemployed in urban getting insurance. In the urban areas the United States since 1938 provisions apply maximum working hours and minimum wage.

The study is based political economy perspective suggests that the Great Depression occurred during the period 1929 to the beginning of 1940 brought disorder to the US economy because the gap that separates rich and poor are very keen to be marked by the collapse of the drastic economic production, delays in product marketing and commodities and stagnation in the services sector, is really going on unemployment and poverty are very broad. The Great Depression illustrates the fundamental weaknesses in the US economy. On the surface, the 1920s is considered as a period of prosperity in the US terciptanyan formation. But on the other hand occurs imbalance in the US economy due to hit by problems, Robert S McElvaine states: The wealthy made large profits, but more and more Americans spent, more than they earned, and farmeds faced low prices and heavy debt ... Income was distributed very unevenly and portion going to the wealthies Americans Grew large as the decade proceedeed.

US case actually shows us the search aternatif against lassez faire doctrine in economic governance fully gain the support of political liberalism. In the era of Fraklin D.Roosevelt, laissez faire is an alternative to the welfare state, what was done by the US President mangadopsi spirit of the welfare state. A finding of existence of the welfare state and the shape format in the US state in the era of Franklin D.Roosevelt.

Listened to the results achieved by President Franklin D.Roosevelt, in his own way, to make efforts negation of lassez faire doctrine. When the doctrine was considered incompatible with zeigest, it is necessary to make corrections. In line with theory embodied in political philosophy Isaiah Berlin, then the responsibility of the state to the citizens never increasingly shrinking and shrinking, but rather increasingly large and continues to grow, in line with the revolving period to the court of the future of an increasingly complex, "Responsibility of the state to its cirizens, according to the authors become must and will and will grow and not diminish'.

According Iasah Berlin, in the New Deal of President Roosevelt Fraklin there is a political possions able to find a formula for a constructive compromise between individual freedom and economic stability. Inter-individual freedom and economic stability should not be mutually relativize one another. President Fraklin economic policy is to create a meeting point between two things that are very important in the governance of the state and society. According to both economic Nobel Prize winner in 1974, Friedrich August von Hayek (1899 to 1992), President Riosevelt is already trying to realize a meeting point between individuals and economic order, so as not to destroy marginal groups. What had been a shift lazessfaire pendulum is shifting the orientation of the economy because of the emergence of new challenges. Introduction laissez faire rests on the basis of extreme exaltation of the market mechanism. Assuming the market is able to create a new balance immediately, state intervention in the citizens as something irrelevant. Instead pendulum welfare state, does not believe in the willingness of the market in terms of creating a new balance that is fair. That is why, the regulation of state intervention in the workings of the market as an inevitability.

The division of powers is actually a delegation of power from the people as the sovereign 
people as stipulated in Article 2 paragraph 1 of the Constitution of 1945. But this agency is not an institution that serves as the representative body of the people because there is a state institution again that Parliament has the power in Article 2 paragraph (1), jo.Pasal 19. Articles 20,21 and 22, 1945.

Sri Soemantri said that the Indonesian government system before 1945 was amended almost the same as the system of government in France, which shows a mixture of parliamentary system of government with a presidential system of government. However, since 2004 the Indonesian president elected directly by the people democratically. Although the President directly responsible to the people, but if the President in violation of Article 7A of the 1945 Constitution, the House of Representatives as members of the Assembly can lay claim to the President of the Court. It shows that the system of government in Indonesia after the amendment of the similarity to the division of powers in the American system of government, because the concept of running the government on the one hand there is the Executive. The division of powers is seen there is a law that regulates deep inside himself.

The concept is set only for its own interests by Philip Selnick failed because the law only seen in the legislation area, but the law must be approached in a more holistic method for decisionmakers legislative, executive and law enforcement should look to the integrity of the human life. Speaking enforcement substantially related to legal liability widely talks. Talking about ideas that require a fairly complex organization like a country. The state should intervene in the embodiment of the law are realized by forming a wide variety of bodies for this purpose (legal autonomous), but the bodies are seen as an organization that stands alone in carrying out the same task is to realize the law or enforce the law in society (responsive law). Although the law has a vision harmonize responsive powers and ignore the institutional boundaries, there remains a distinction between legal decisions and political decisions that can not be eliminated. Instead, the legal process which aims to enlarge the competence of the legal institution considers that: i). Design and institutional evaluation can be built on-premise received decisive destinations served by law and ii). Legal task is to reduce the arbitrariness in defining and elaborating these objectives.

Abstract legal purpose in the midst of a complex society can only be realized through a complex organization as well. Through the organization and the processes ongoing in the process, the community received a manifestation of the purposes of law, justice for example, is given to members of the public in the ratification of certain actions. Order and security becomes something tangible through the actions of law enforcement officers, as well as legal certainty with the judge's decision.

Can also be said that the law enforcement always involve human behavior, the law can not be upright by itself means being able to realize its own promises and the will stated in legal regulations such as providing for the welfare of another person without the action of the executive power.

In a Presidential system of government adopted in 1945 and also the system is generally defined as an entity consisting of elements relate to each other and influence each other, so it is a unified whole and meaningful. In view of the government system based on modern legal system that is used widely by the countries in the world with the doctrine of "rule of law" is referred to as the legal system (legal system), which discuss the legal aspects of systematic, meaning that revolves around the rules of law and decisions of judges prevailing in a society that has nothing to do with each other. In this system of justice is considered granted to make positive law and justice would be established and specified in the positive law (legislation). 
Theorizing about the legal system can be understood in legal characteristics as a building system (idea) and rationality. The use of the concept of the idea of $\square \square$ the law is not only rational system, but also building the ideas, values $\square \square$ and realities of life in a single unit to create a specific pattern in the life of a nation. Therefore the law is not seen, understood and treated as an agency separate sharply from the sub-system within the community. The use of the concept of the idea that is intended as a road used a nation to determine its own legal system.

The development of law in the country postliberal increasingly seeing a rise in standards bending (open ended standards), purposive approach towards legal and procedural and substantive law approach to justice that are directly related to the dynamics in the welfare state increasingly to the fore. The existing system of government in the constitution as written and unwritten law must increasingly be able to ensure that the ideals of justice prosperous society can be achieved.

Currently the social moral decline in this country almost at the bottom nadir. Almost all cases are dealt with half-heartedly, ranging from the mudflow in Sidoarjo, Bank Century, until the tax and legal mafia. This is a bit of an example of complete demoralization presenting in Indonesia.

One of the root problems that decrease nations into pools of demoralization is split between diversity and democracy. Each running its own without a synergistic linkage between the two. Honestly, the diversity of which rose around us more manifest themselves in the form indivudual based or group-based religiosity Consequently models this diversity tends to ignore the values of universal morality religious teachings that should be the reference and the basis for reference in solving all kinds of problems of human life with all its diversity. Religion is dragged into for thickening identity is often contrasted with the symbols or even the existence outside the group.

As runs his own religion, democracy is also strong in this country seem to take the same road. Democracy conceived and executed with the term Fareel Zakaria in The Future of Freedom just as the governance process. If the run is followed multiparty elections and appear to be competitive, then it called with democracy. Making of democracy as a democracy will make the surface wild interpretation. In the banality of democracy serve as a shield to cover up immorality. The name of democracy, the elements of the state and people competing to affirm its own interests and the common interests of the group and put the altar of sacrifice. Democracy apart from the substance of the meaning that would give birth to a new form of corrupt dictators and anarchic society and people do not want to miss through camouflage freedom of expression, they are protesting anarchists who are no longer with constructive criticism but squeeze a person or institution of their critics.

Demoralized almost a tradition in public life can be eliminated through the actualization of values morality into the system policy that reaches all aspects of political, social, education to economics. This building must be such that the development beetwen religion and democracy become a necessity that must be developed. Because true democratic principles Abd Karim said Sorous in 'Suing Authority and Tradition Religion' is moral. Democracy is basically a method to limit the power of government. In that frame, justice has been done, developed and other noble morality anchored in life. Therefore, according to Sorous, democracy will not succeed if the absence of a commitment to morality as a bastion of religion as metahistoris truth noble values of religion. 


\section{CONCLUSION}

In some countries social security for citizens in place to protect marginalized groups in order to maintain access to public services are rudimentary, such as services to meet the needs from the perspective of political economy known as basic need. Public welfare provision in the state system includes services in the areas of basic education, health and housing are cheap and good quality, if necessary, free as in Western Europe is a cluster of countries are quite intense in terms of run-rinsip principles of the welfare state. Free education and health is a major concern in Western Europe to get subsidies. The data agency said the Indonesian population in 2010 income Rp.27,0 million a year. There are poor people whose population is 80 percent of the population only contributes about 20 percent of GDP. There are the wealthy once or people who enter the category earn more than 30,000 dollars a year, but there are also people with disabilities living income or $\$ 2$ dollars per day ( 730 dollars a year), which are still 100 million people. It means there is a huge gap. The words fair, equitable, well-being and prosperity was growing dimmer and the faint sound. This condition shows how there is no equity in income because there is no strong will to realize the vision for the welfare of society. Impossible antipoverty program run properly if the governance of the state and society is not yet fully based on the welfare state system. Anti-poverty programs intertwine with the application of individual taxation that is progressive. If taxation without concept, poverty reduction strategy with the government has not gone according to terms of the welfare state that is pro-poor.

\section{REFERENCES}

Alan Greespan, Prahara Ages: Destruction Forecast World Economy of the 21st Century, translation Tome Beka, Gramedia, Jakarta

Arief Hidayat, Freedom of Association in Indonesia An Analysis of Effects of Changes in Political System Against Law Interpretation, Diponegoro University, Semarang, 2009

FA. Hayek, Individulisme and Economic Order, Chikago and London, The Univesity of Chicago Press, 1992 [1948].

Francis Fukuyama, The End of History and the Last Man, New York, The Free Press, 1992

Haris Rahimi, Politics and Government of Indonesia, MIPI Center 2009

J.J. Bruginkk, Reflections on the Law, Aditya Citra Bhakti, Bandung, 1999

Jacques B Gelinas, Juggernaut, Politics: Understanding Predatory Globalization, New York, Zed books, 2003

Joseph Stiglitz, The Roaring Nineties: Why We're Paying the Price for the Greedies Decade and History, Londone, Penguin Book 2003

Stephen Y. Kotan, Meaning the State Government Powers According to Section III of the 1945 Constitution and Its Relationship With Presidential Affairs Institute, Disertasi, Graduate Padjadjaran, Bandung 2000

Philip Nonet and Philip Selznick in Satjipto Rahardjo, Law In Order Jagat, UKI Press, Jakarta

Robert S McEvaine, The Great Depression in the United State, in Microsoft Student 2007 (DVD), WA, Microsoft Corporation, 2006.

Roberto M. Unger, Critical Legal Theory, Legal Position In Modern Society, Nusamedia, Jakarta. 
Sri Suatmiati : Implementation Of The Development Program That Just As The Pro-poor ......

Sri Soemantri M. MPR Decree (S) as One Source HTN Affairs, Youth Work, Bandung, 1988

Tjahya Gunawan Diredja, Economic Development Model, Indonesia No Need to Fear Copying China, Kompas, December 21, 2010 